\title{
Implementasi Pembelajaran Pendidikan Agama Islam pada Masa Pandemi Covid-19
}

\author{
Ach Chairy', Istiqomah ${ }^{2}$ \\ 1,2IAI Agus Salim Lampung, Indonesia \\ E-mail: chairy12345@gmail.com, istiqomahagussalim@gmail.com
}

\begin{tabular}{|c|c|}
\hline Article Info & Abstract \\
\hline Article History & This study describes the study of the implementation of Islamic religious education \\
\hline Received: $2021-12-27$ & learning during the COVID-19 pandemic. The method used in this study uses a library \\
\hline $\begin{array}{l}\text { Revised: } 2022-01-22 \\
\text { Published: } 2022-02-03\end{array}$ & research method or approach, that library research can be interpreted as a series of \\
\hline & $\begin{array}{l}\text { activities related to the methods of collecting library data, reading and taking notes and } \\
\text { processing research materials. The results of this study indicate that the Covid-19 }\end{array}$ \\
\hline Keywords: & pandemic has had a significant impact on various sectors including education. The \\
\hline $\begin{array}{l}\text { Learning; } \\
\text { Islamic; }\end{array}$ & Covid-19 pandemic provides social restrictions for teachers and students, so that the \\
\hline $\begin{array}{l}\text { Islamic; } \\
\text { Education; }\end{array}$ & spirit of learning must still be carried out. Learning Islamic Religious Education is one \\
\hline Pandemic; & of the components of subjects that must be carried out by teachers to instill religious \\
\hline Covid-19 & values in students so that they become human beings who believe and are pious as the \\
\hline & goals of national education. The implementation of the Islamic Religious Education \\
\hline & $\begin{array}{l}\text { learning process remotely requires educators to redesign and suddenly in order to be } \\
\text { able to utilize information technology optimally in a fun way from the learning }\end{array}$ \\
\hline
\end{tabular}

\begin{tabular}{l}
\hline Artikel Info \\
Sejarah Artikel \\
Diterima: $2021-12-27$ \\
Direvisi: $2022-01-22$ \\
Dipublikasi: $2022-02-03$
\end{tabular}

Kata kunci:

Pembelajaran;

Pendidikan;

Agama Islam;

Pandemi;

Covid-19.

\begin{abstract}
Abstrak
Penelitian ini menjelaskan tentang kajian terhadap implementasi pembelajaran pendidikan agama islam pada masa pandemi covid-19. Metode yang digunakan dalam kajian ini menggunakan metode atau pendekatan kepustakaan (library research), bahwa studi pustaka atau kepustakaan dapat diartikan sebagai serangkaian kegiatan yang berkenaan dengan metode pengumpulan data pustaka, membaca dan mencatat serta mengolah bahan penelitian. Hasil penelitian ini menunjukkan bahwa pandemi Covid-19 memberikan dampak yang signifikan terhadap berbagai sektor termasuk pendidikan. Pandemi Covid-19 memberikan pembatasan sosial terhadap guru dengan peserta didik, sehingga semangat belajar tetap harus terlaksana. Pembelajaran Pendidikan Agama Islam merupakan salah satu komponen mata pelajaran yang harus dilaksanakan guru untuk menanamkan nilai-nilai agama kepada peserta didik supaya menjadi manusia yang beriman dan bertaqwa sebagaimana tujuan pendidikan nasional. Pelaksanaan proses pembelajaran Pendidikan Agama Islam dengan jarak jauh menuntut pendidik untuk mendesain ulang dan secara mendadak agar dapat memanfaatkan teknologi informasi secara optimal dengan menyenangkan dari mulai perencanaan pembelajaran, penggunaan media pembelajaran, alokasi waktu, dan penilaian hasil belajar.
\end{abstract}

\section{PENDAHULUAN}

Merebaknya virus covid-19 diseluruh dunia berdampak pada seluruh sendi kehidupan, salah satu yang terdampak oleh pendemi ini adalah dunia pendidikan tidak luput dari dampak COVID-19 ini, pandemi Covid-19 memberikan dampak yang signifikan terhadap berbagai sektor. Pendidikan merupakan salah satu sektor yang juga merasakan dampak dari pandemi Covid-19 (Arifudin, 2020), pandemi Covid-19 memberikan pembatasan sosial terhadap guru dengan murid sehingga semangat belajar tetap harus terlaksana. Menteri Pendidikan dan Kebudayaan RI Nadiem Anwar Makarim mengeluarkan Surat Edaran Nomor 4 tanggal 19
Maret 2020 tentang pelaksanaan penddidikan dalam masa darurat penyebaran COVID-19, dalam isi surat pada nomor 2 yang intinya menyatakan bahwa proses kegiatan belajar mengajar dilakukan dari rumah melalui pembelajaran daring atau jarak jauh, tujuannya untuk kesehatan lahir dan batin peserta didik, guru, kepala sekolah, dan seluruh warga sekolah (Surat Edaran Nomor 4 Tahun 2020 tentang Pelaksanaan Kebijakan Pendidikan dalam Masa Darurat Penyebaran Corona Virus Disease (COVID-19), 2020), dengan kebijakan tersebut, proses pem-belajaran disemua jenjang pendidikan dilaksana-kan dari rumah dengan Pembelajaran Jarak Jauh melalui dalam jaringan 
(online) dan luar jaringan (off line), dengan diberlakukannya pembelajaran daring, berimplikasi (mempunyai hubungan keterlibatan langsung) terhadap perencanaan strategi guru dalam melakukan kegiatan pembe-lajaran, yang tentunya memerlukan perencanaan strategi berbeda dari perencanaan strategi pembelajaran tatap muka (Darmayani, 2021), untuk itulah penelitian ini dilakukan dalam rangka menilik bagaimana perencanaan strategi guru dalam pembelajaran Pendidikan Agama Islam melalui pembelajaran daring.

Kesiapan orang tua diperlukan dalam pembelajaran jarak jauh yakni sabar, percaya diri, dan tenang dalam membimbing anak, kendalanya anak mudah marah, menangis dan melawan akibat tugas terlalu banyak dan bingung untuk bertanya sehingga semangat belajar menurun (Nasser, 2021). Sarannya guru dalam mengajar membuat video dan atau pembelajaran menggunakan aplikasi Zoom, selain itu juga menggunakan Google Classroom, Google Forms, Whatsapp, Facebook dan Metode Discovery Learning sehingga dari penelitian-penelitian terdahulu terlihat belum ada kajian khusus terkait dengan proses implementasi yang dilakukan oleh guru dalam proses pembelajaran daring saat ini. Pembelajaran daring tentunya memberikan tekanan yang sangat tinggi terhadap aktivitas mengajar bagi guru, bahkan tidak sedikit guru yang harus mnegeluarkan tenaga ekstra demi telaksananya pembelajaran daring sesuai yang diharapkan (Tanjung, 2019). Tekanan dalam pembelajaran online tentunya tidak sama dengan pembelajaran tatap muka, jika dalam pembelajaran tatap muku guru tidak akan disibukkan dengan membangun aturan-aturan baru namun saat pembelajaran daring guru harus disibukkan dengan aturan-aturan yang harus mereka bentuk kembali dan harus disepakati. Sehingga banyak juga guru yang mengalami lelah dan stres dalam pembelajaran daring ini (Supriani, 2022).

Namun faktanya saat ini tidak sedikit sekolah yang masih kesulitan melaksanakan proses pembelajaran yang update melalui pemanfaatan teknologi informasi, memilih strategi pembelajaran yang menarik, memilih metode pembelajaran terhadap peserta didik pada proses pembelajaran daring. Seringnya pendidik dituntut memiliki sikap terbuka dan tanggap terhadap berbagai perubahan hal ini dikarenakan perubahan tersebut memberikan pengaruh besar terhadap proses pembelajaran (Ulfah, 2022). Kesulitan ini bukan hanya muncul dari pendidik saja akibat perintah secara mendadak dalam melakukan pembelajaran jarak jauh melainkan juga faktor lainnya, banyak sekali kendalakendala yang ditemukan ketika sekolah dituntut untuk melaksanakan proses pembelajaran daring terutama guru yang merasakan sebagai pelaksana.

\section{METODE PENELITIAN}

Sesuai dengan karakteristik masalah yang diangkat dalam penelitan ini maka menggunakan Metode Riset kualitatif yaitu menekankan analisanya pada data deskriptif berupa kata-kata tertulis yang diamati, pendekatan kualitatif penulis gunakan untuk menganalisis kajian terhadap implementasi pembelajaran pendidikan agama islam pada masa pandemi covid-1, maka dengan sendirinya penganalisaan data ini lebih difokuskan pada Penelitian Kepustakaan (Library Research) yakni dengan membaca, menelaah dan mengkaji buku-buku dan sumber tulisan yang erat kaitannya dengan masalah yang dibahas. Metode yang digunakan dalam kajian ini menggunakan metode atau pendekatan kepustakaan (library research), menurut Zed dalam (Rahayu, 2020) bahwa studi pustaka atau kepustakaan dapat diartikan sebagai serangkaian kegiatan yang berkenaan dengan metode pengumpulan data pustaka, membaca dan mencatat serta mengolah bahan penelitian.

Jenis penelitian ini adalah penelitian kualitatif, menurut Ibnu dalam (Arifudin, 2019) penelitian kualitatif adalah suatu penelitian yang datanya dinyatakan dalam bentuk verbal dan dianalisis tanpa menggunakan teknik statistik, berdasarkan beberapa definisi penelitian kualitatif di atas, dapat disimpulkan bahwa penelitian kualitatif adalah suatu penelitian yang datanya dinyatakan dalam bentuk verbal, tidak menggunakan angka dan analisisnya tanpa menggunakan teknik statistik.

1. Objek Penelitian

Dalam penelitian ini objek penelitian terdiri dari 2 (dua), yaitu objek formal dan objek material (Arifudin, 2018). Objek formal dalam penelitian ini berupa data yaitu data yang berhubungan dengan tinjauan kritis kajian terhadap implementasi pembelajaran pendidikan agama islam pada masa pandemi covid-19, sedangkan objek materialnya berupa sumber data, dalam hal ini adalah tinjauan kritis kajian terhadap implementasi pembelajaran pendidikan agama islam pada masa pandemi covid-19. 
2. Waktu Penelitian

Penelitian ini dilaksanakan pada bulan agutus sampai dengan desember tahun 2021.

3. Teknik Pengumpulan Data

Pengumpulan data yang dilakukan dengan menggunakan teknik dokumentasi yaitu mengadakan survey bahan kepustakaan untuk mengumpulkan bahan-bahan dan studi literatur yakni mempelajari bahan-bahan yang berkaitan dengan objek penelitian, teknik pengumpulan data menurut (Bahri, 2021) mengemukakan bahwa merupakan langkah yang paling strategis dalam penelitian karena tujuan untama dari penelitian adalah mendapatkan data. Terdapat beberapa cara atau teknik dalam mengumpulkan data, diantaranya adalah observasi dan dokumentasi. Sumber data yang digunakan dalam penelitian ini mencakup data primer dan sekunder. Menurut (Hanafiah, 2021) bahwa data primer adalah data yang dikumpulkan langsung dari individu-individu yang diselidiki atau data tangan pertama, sedangkan data sekunder adalah data yang ada dalam pustaka-pustaka. Data primer dalam penelitian ini adalah bukubuku terkait tinjauan kritis kajian terhadap implementasi pembelajaran pendidikan agama islam pada masa pandemi covid-19, dan data sekunder didapatkan dari jurnaljurnal baik nasional maupun inter-nasional.

4. Alat Pengumpulan Data

Dalam penelitian ini penulis akan menggunakan metode dokumentasi sebagai alat untuk pengumpul data karena penelitian ini adalah penelitian kepustakaan, dengan kata lain menurut (Juhji, 2020) bahwa teknik ini digunakan untuk menghimpun data-data dari sumber primer maupun sekunder.

5. Teknik Analisis Data

Analisis data tidak saja dilakukan setelah data terkumpul, tetapi sejak tahap pengumpulan data proses analisis telah dilakukan, penulis menggunakan strategi analisis "kualitatif", strategi ini dimaksudkan bahwa analisis bertolak dari data-data dan bermuara pada kesimpulan-kesimpulan umum. Berdasarkan pada strategi analisis data ini, dalam rangka membentuk kesimpulan-kesimpulan umum analisis dapat dilakukan menggunakan kerangka pikir "induktif". Menurut (Sugiyono, 2015) bahwa metode pembahasan menggunakan metode deskriptif-analisis yaitu menjelaskan serta mengelaborasi ide-ide utama yang berkenaan dengan topik yang dibahas. Kemudian menyajikannya secara kritis me- lalui sumber-sumber pustaka primer maupun skunder yang berkaitan dengan tema.

6. Prosedur Penelitian

Data pada penelitian ini dicatat, dipilih dan kemudian diklasifikasikan sesuai dengan kategori yang ada. Pendekatan yang digunakan adalah pendekatan deskriptif analitis. Menurut (Nadeak, 2020) bahwa deskriptif analitis (descriptive of analyze research) yaitu pencarian berupa fakta, hasil dari ide pemikiran seseorang melalui cara mencari, menganalisis, membuat interpretasi serta melakukan generalisasi terhadap hasil penelitian yang dilakukan. Prosedur penelitian ini (Tanjung, 2022) adalah untuk menghasilkan data deskriptif yang berupa data tertulis setelah melakukan analisis pemikiran (content analyze) dari suatu teks. Setelah penulis mengumpulkan bahan-bahan yang berhubungan dengan masalah yang akan di bahas dalam penelitian ini, kemudian penulis menganalisis dan menarasikan untuk diambil kesimpulan.

\section{HASIL DAN PEMBAHASAN}

Dalam pembahasan ini akan dibahas tentang perencanaan pembelajaran, penggunaan media pembelajaran, alokasi waktu dalam pembelajaran, dan penilaian hasil belajar.

1. Perencanaan Pembelajaran

Dalam pelaksanaan pembelajaran daring sangat berbeda dengan pelaksanaan pembelajaran tatap muka. Seorang guru harus mempersiapkan berbagai hal termasuk jaringan internet dan penggunaan aplikasi pembelajaran. Guru Pendidikan Agama Islam secara khusus harus mampu mengoperasikan perangkat internet yang digunakan dalam pembelajaran Pendidikan Agama Islam secara daring (Tanjung, 2020). Perencanaan merupakan rangka sesuatu yang akan dikerjakan. Salah satu perencanaan guru dalam pembelajaran yakni menyiapkan rencana pelaksanaan pembelajaran (RPP) yang merupakan pedoman untuk kegiatan belajar mengajar, agar pelaksanaan pembelajaran berjalan dengan baik dan mendapat-kan tujuan pembelajaran sesuai keinginan (Vidiarti, 2019). Setiap guru yang mengajar diwajibkan membuat rencana pelaksanaan pembelajaran daring dan dibuat satu lembar setiap satu kali pertemuan untuk setiap pokok bahasan materi pelajaran yang akan diajarkan kepada peserta didik. Ini dilakukan guru sesuai dengan surat edaran menteri pendidikan dan 
kebudayaan nomor 14 tahun 2019 tentang Penyederhanaan Rencana Pelaksanaan Pembelajaran. Perencanaan pembelajaran PAI diawali dari pembuatan rencana pelaksanaan pembelajaran daring yang berpedoman pada kurikulum 2013, dan dibuat sesederhana mungkin yaitu satu pokok bahasan untuk satu kali pertemuan dibuat satu lembar, dibuatnya atas inisiatif sendiri karena tidak ada pedoman untuk membuat dari kemendikbud, dalam hal ini diperlukan berbagai inovasi dari seorang guru agar dapat meminimalisir berbagai hambatan pelaksanaan pembelajaran daring dengan mengoptimalkan berbagai inovasi baru dalam beradaptasi dengan pelaksanaan pembelajaran daring di masa kini, hal ini pun tidak menutup kemungkinan di masa mendatang guru harus menguasai perangkat internet dalam menghadapai era digitalisasi.

\section{Penggunaan Media Pembelajaran}

Pelaksanaan pembelajaran daring sama hal nya dengan pembelajaran tatap muka membutuhkan peran media pembelajaran dalam mengoptimalkan setiap pemberia materi oleh guru pada peserta didik. Media pembelajaran pada pelaksanaan pembelajaran daring akan sangat berbeda penggunaanya karena peserta didik tidak dapat menggunakan atau mensimulasikan secara langsung setelah mendapat contoh dari gurunya. Media dalam pelaksanaan kegiatan pelaksanaan pembelajaran daring sangatlah penting sebagai alat penyampai atau pengantar konten-konten pelajaran guru kepada peserta didik, tanpa adanya media proses pembelajaran tidak dapat dilaksanakan. Menurut Association of Education and Communication Technology, media adalah alat yang menyampaikan atau mengantarkan pesan-pesan pengajaran (Sofyan, 2020), dlam kegiatan belajar mengajar daring, guru dapat menggunakan berbagai aplikasi seperti WhatsApp Group, Google Forms, dan Zoom. Penggunaan WhatsApp untuk kegiatan belajar mengajar dengan membuat grup WhatsApp dalam setiap kelas, zoom digunakan untuk pembelajaran tatap muka dan Google Forms untuk ulangan, membahas soal-soal, penilaian tengah semester, semester dan ujian sekolah dan ujian nasional. dalam penggunaannya bahwa aplikasi WhatsApp, Google Formulir dan Zoom ini merupakan kesepakatan antara pihak sekolah dengan dengan orang tua peserta didik, yang dianggap mudah dalam menggunakannya dan untuk keseragaman.
3. Alokasi Waktu dalam Pembelajaran

Pelaksanaan pembelajaran daring sama hal nya dengan pembelajaran tatap muka membutuhkan alokasi waktu. Dengan berkaca pada RPP yang ada bahwa Pelaksanaan pembelajaran daring akan berbeda mengingat durasi anak di depan layar computer atau smartphone menjadi pertimbangannya. Pelaksanaan kegiatan belajar mengajar yang baik tentunya harus memperhatikan waktu yang akan dimanfaatkan pada saat kegiatan pembelajaran dilaksanakan. Lama-nya waktu pembelajaran dari awal sampai akhir harus disesuaikan dengan kebutuhan peserta didik. Alokasi waktu adalah jumlah waktu yang dibutuhkan untuk tercapainya suatu kompetensi dasar tertentu, dengan memperhatikan minggu efektif per semester, alokasi waktu mata pelajaran per minggu, dan jumlah kompetensi per semester (Purwadi, 2019). Waktu belajar mengajar untuk setiap hari 4 jam 30 menit, pembelajaran daring dimulai pukul 07.00 WIB dan selesai pukul 11.30 WIB. Durasi waktu ini termasuk untuk istirahat peserta didik dan guru, untuk setiap guru diberikan waktu 60 menit, pembagian waktu ini disesuaikan dengan jumlah mata pelajaran dalam setiap harinya, untuk teknis penggunaan waktunya diserahkan pada guru mata pelajaran masing-masing sesuai dengan jadwalnya.

4. Penilaian Hasil Belajar

Dalam menghasilkan capaian pembelajaran sesuai dengan tujuan pembelajaran, diperlukan strategi dalam proses pembelajaran daring. Guru seyogyanya memiliki strategi atau penggunaan pendekatan pembelajaran yang baik. Seorang guru pengajar yang professional tidak hanya berfikir tentang apa yang akan dikerjakan, tetapi juga tentang siapa menerima pelajaran, apa makna belajar bagi peserta didik, dan kemampuan apa yang ada pada peserta didik dalam mengikuti pembelajaran. Ada beberapa jenis strategi pembelajaran yang dapat diterapkan guru yaitu strategi pembelajaran ekspositori, inquiri, berbasis masalah, koorporatif, contextual teaching and learning (CTL) (Tanzimah, 2020). Beberapa strategi pembelajaran yang dapat ditempuh guru adalah dengan memberi tugas hafalan ayat-ayat al-Qur'an dan Hadits, peserta didik merekam hafalannya dalam bentuk video lalu dikirim ke guru melalui WhatsApp, yang salah diperbaiki, kemudian diadakan pengkajian tentang isi dan 
kandungan ayat-ayat tersebut. Aspek yang dinilai berkenaan dengan hasil kemampuan belajar peserta didik meliputi pengetahuan, keterampilan, sikap dan penguasaan terhadap materi pelajaran yang telah diberikan, waktunya dilaksanakan setiap akhir pelaksanaan suatu program belajar mengajar (setiap akhir pelajaran). Penilaian formatif sebagai follow up kepada peserta didik, dilakukan setelah kegiatan pembelajaran dilaksanakan, pelaksanaannya setiap bab yang menjadi kompetensi dasar selesai dipelajari, bentuknya ulangan harian dengan memberikan tugas, keaktifan peserta didik dalam pembelajaran (kehadiran, bertanya dan menjawab pertanyaan) menjadi bahan pertimbangan dalam memberikan nilai pada peserta didik.

\section{SIMPULAN DAN SARAN}

\section{A. Simpulan}

Berdasarkan pemaparan pada penelitian implementasi pembelajaran pendidikan agama islam pada masa pandemi covid-19 ini dapat disimpulkan bahwa pandemi Covid-19 memberikan dampak yang signifikan terhadap berbagai sektor termasuk pendidikan. Pandemi Covid-19 memberikan pembatasan sosial terhadap guru dengan peserta didik, sehingga semangat belajar tetap harus terlaksana. Pembelajaran Pendidikan Agama Islam merupakan salah satu komponen mata pelajaran yang harus dilaksanakan guru untuk menanamkan nilai-nilai agama kepada peserta didik supaya menjadi manusia yang beriman dan bertaqwa sebagaimana tujuan pendidikan nasional. Pelaksanaan proses pembelajaran Pendidikan Agama Islam dengan jarak jauh menuntut pendidik untuk mendesain ulang dan secara mendadak agar dapat memanfaatkan teknologi informasi secara optimal dengan menyenangkan dari mulai perencanaan pembelajaran, penggunaan media pembelajaran, alokasi waktu, dan penilaian hasil belajar.

\section{B. Saran}

Pembahasan terkait penelitian kajian terhadap implementasi pembelajaran pendidikan agama islam pada masa pandemi covid-19 dalam penelitian ini masih sangat terbatas dan membutuhkan banyak masukan. Saran untuk penulis selanjutnya adalah mengkaji lebih dalam dan secara kom-prehensif terkait kajian terhadap im-plementasi pembe- lajaran pendidikan agama islam pada masa pandemi covid-19.

\section{DAFTAR RUJUKAN}

Anam. (2021). Manajemen Kurikulum Pembelajaran PAI. Ta'limdiniyah: Jurnal Pendidikan Agama Islam (Journal Of Islamic Education Studies)., 1(2), 129-143.

Arifudin, O. (2018). Pengaruh Pelatihan Dan Motivasi Terhadap Produktivitas Kerja Tenaga Kependidikan STIT Rakeyan Santang Karawang. MEA (Manajemen, Ekonomi, \& Akuntansi), 2(3), 209-218.

Arifudin, O. (2019). Manajemen Sistem Penjaminan Mutu Internal (SPMI) Sebagai Upaya Meningkatkan Mutu Perguruan Tinggi. MEA (Manajemen, Ekonomi, \& Akuntansi), 3(1), 161-169.

Arifudin, O. (2020). Pandemi Corona Dan Dampak Terhadap Dunia Pendidikan. Dalam https://www.pasundanekspres.co/pandemicorona-dan-dampak-terhadap-duniapendidikan. Diakses 10 Mei 2020.

Arifudin, 0. (2021). Konsep Dasar Pendidikan Anak Usia Dini. Bandung: Widina Bhakti Persada Bandung.

Bahri, A. S. (2021). Pengantar Penelitian Pendidikan (Sebuah Tinjauan Teori dan Praktis). Bandung: Widina Bhakti Persada.

Bairizki, A. (2021). Manajemen Perubahan. Bandung: Widina Bhakti Persada.

Daheri. (2020). Efektifitas Whatsapp Sebagai Media Belajar Daring. Jurnal Basicedu, 4(4), 775-783.

Darmawan, I. P. A. (2021). Total Quality Management Dalam Dunia Pendidikan" Model, Teknik Dan Impementasi". Bandung: Widina Bhakti Persada Bandung.

Darmayani, S. (2021). Pembelajaran Digital. Bandung : Widina Bhakti Persada.

Hanafiah, H. (2021). Pelatihan Software Mendeley Dalam Peningkatan Kualitas Artikel Ilmiah Bagi Mahasiswa. Jurnal Karya Abdi Masyarakat, 5(2), 213-220. 
Hasbi, I. (2021). Administrasi Pendidikan (Tinjauan Teori Dan Praktik). Bandung: Widina Bhakti Persada.

Ilyas. (2019). Konsep Kesiapan Siswa Dalam Mengerjakan Tugas. Schoulid: Indonesian Journal Of School., 1(2), 33-38.

Irwansyah, R. (2021). Perkembangan Peserta Didik. Bandung : Widina Bhakti Persada.

Iswahyudi. (2020). Evaluasi Program Boarding School Dalam Upaya Meningkatkan Mutu Lulusan Di Man 1 Gunungkidul. Jurnal Pendidikan Madrasah., 5(2), 165-172.

Juhji. (2020). Manajemen Humas Sekolah. Bandung: Widina Bhakti Persada.

Khamim. (2019). Penerapan Pendidikan Agama Islam Pada Keluarga Millenial. Attaqwa: Jurnal Ilmu Pendidikan Islam., 15(2), 132142.

Lubis. (2020). Pembelajaran PAI Era Covid -19 Di Rantau Prapat Kabupaten Labuhan batu. Jurnal Pendidikan, Agama Dan Sains, 4(1), 66-75.

Ma'ruf, F. (2021). Pengembangan Game Edukasi Berbasis Flash Sebagai Sarana Belajar Siswa PAUD. Ainara Journal (Jurnal Penelitian Dan PKM Bidang Ilmu Pendidikan),2(3), 143147. https://doi.org/10.54371/ainj.v2i3.68

Mayasari, A. (2021). Implementasi Sistem Informasi Manajemen Akademik Berbasis Teknologi Informasi dalam Meningkatkan Mutu Pelayanan Pembelajaran di SMK. JIIPJurnal Ilmiah Ilmu Pendidikan, 4(5), 340345. https://doi.org/10.54371/jiip.v4i5.277

Muhsin. (2019). Pengaruh Motivasi Belajar, Disiplin Belajar, Cara Belajar Dan Interaksi Teman Sebaya Terhadap Kesiapan Belajar. Economic Education Analysis Journal., 8(1), 318-332.

Mulyasa. (2002). Manajemen Berbasis Sekolah, Konsep, Strategi, dan Implementasi. Bandung: PT. Remaja Rosdakarya.

Na'im, Z. (2021). Manajemen Pendidikan Islam. Bandung: Widina Bhakti Persada.
Nadeak, B. (2020). Manajemen Humas Pada Lembaga Pendidikan. Bandung: Widina Bhakti Persada.

Nasser, A. A. (2021). Sistem Penerimaan Siswa Baru Berbasis Web Dalam Meningkatkan Mutu Siswa Di Era Pandemi. Biormatika: Jurnal Ilmiah Fakultas Keguruan Dan Ilmu Pendidikan, 7(1), 100-109.

Pasaribu. (2019). Model Integratif Pendidikan Seks, cet I. Yogyakarta: Bildung.

Purwadi. (2019). Penerapan Lembar Kegiatan Siswa (Lks) Pada Kompetensi Dasar Menerapkan Teknik Dasar Perhitungan Azimuth. Jurnal Kajian Pendidikan Teknik Bangunan, 5(1), 51-62.

Rahayu, Y. N. (2020). Program Linier (Teori Dan Aplikasi). Bandung : Widina Bhakti Persada.

Razaq. (2019). Internalisasi Nilai-Nilai Keislaman Terhadap Perkembangan Anak Di Sekolah Dasar Muhammadiyah Kriyan Jepara. Profetika: Jurnal Studi Islam., 2(1), 16-29.

Sa'dullah. (2020). Pandemi Covid-19 Dan Implikasinya Terhadap Pembelajaran Pendidikan Agama Islam Di SMPN 1 Banyubiru Kabupaten Semarang. Salatiga: IAIN Salatiga.

Siregar. (2008). Mozaik Teknologi Pendidikan. Jakarta: Kencana.

Sofyan, Y. (2020). Peranan Konseling Dosen Wali Dalam Meningkatkan Motivasi Belajar Mahasiswa Di Perguruan Tinggi Swasta Wilayah LLDIKTI IV. Jurnal Bimbingan Dan Konseling Islam, 10(2), 237-242.

Sugiana. (2019). Pengembangan Kurikulum Pendidikan Agama Islam Dan Implementasinya Di Mts Nurul Ummah Yogyakarta. Jurnal Pendidikan Agama Islam, 16(1), 17-34.

Supriani, Y. (2022). Peran Manajemen Kepemimpinan dalam Pengelolaan Lembaga Pendidikan Islam. JIIP-Jurnal Ilmiah Ilmu Pendidikan, 5(1), 332-338. 
Tanjung, R. (2019). Manajemen Pelayanan Prima Dalam Meningkatkan Kepuasan Mahasiswa Terhadap Layanan Pembelajaran (Studi Kasus di STIT Rakeyan Santang Karawang). MEA (Manajemen, Ekonomi, \& Akuntansi), 3(1), 234-242.

Tanjung, R. (2020). Pengaruh Penilaian Diri Dan Efikasi Diri Terhadap Kepuasan Kerja Serta Implikasinya Terhadap Kinerja Guru. Jurnal Ilmiah MEA (Manajemen, Ekonomi, Dan Akuntansi), 4(1), 380-391.

Tanjung, R. (2021). Kompetensi Manajerial Kepala Sekolah Dalam Meningkatkan Kinerja Guru Sekolah Dasar. JIIP-Jurnal Ilmiah Ilmu Pendidikan, 4(4), 291-296. https://doi.org/10.54371/jiip.v4i4.272

Tanjung, R. (2022). Manajemen Penyelenggaraan Pendidikan Inklusi pada Lembaga Pendidikan Islam. JIIP-Jurnal Ilmiah Ilmu Pendidikan, 5(1), 339-348.
Tanzimah. (2020). Keterkaitan Model Pembelajaran Think Pair Share (TPS) Dengan Pendekatan Contextual Teaching And Learning (CTL) Dalam Pembelajaran Matematika. Jurnal Dosen Universitas PGRI Palembang, 1(1), 762-772.

Ulfah, U. (2022). Kepemimpinan Pendidikan di Era Disrupsi. JIIP-Jurnal Ilmiah Ilmu Pendidikan, 5(1), 153-161.

Vidiarti. (2019). Analisis Kemampuan Guru Pendidikan Agama Islam Dalam Penyusunan Rencana Pelaksanaan Pembelajaran (Rpp) Kurikulum 2013. J-Pai: Jurnal Pendidikan Agama Islam., 5(2), 102112.

Warianie. (2020). Peranan Penting Guru, Orang Tua Dan Siswa Dalam Menghadapi Pembelajaran Jarak Jauh Di Masa Pandemi Covid 19. Enggang: Jurnal Pendidikan, Bahasa, Sastra, Seni, Dan Budaya., 1(1), 1629. 